\title{
Pengaruh Kompetensi, Objektivitas, Etika, Integritas, dan Time Budget Pressure terhadap Kualitas Pemeriksaan pada BPK Perwakilan Kalimantan Timur
}

\begin{abstract}
Authors:
Firmansyah $^{1}$

Sarwani ${ }^{2}$

Lili Safrida ${ }^{3}$

Affiliation:

1,2,3 Program Studi Magister Akuntansi, Fakultas Ekonomi dan Bisnis, Universitas

Lambung Mangkurat

Corresponding Author:

Firmansyah

Emails:

${ }^{1}$ firmankap@uwgm.ac.id

${ }^{2}$ sarwani@ulm.ac.id

${ }^{3}$ lilisafrida_Banjar@yahoo.co.id

Article History:

Received : October 24, 2020

Revised : November 17, 2020

Accepted : December 6, 2020

How to cite this article:

Firmansyah., Sarwani., \&

Safrida, L. (2020). Pengaruh

Kompetensi, Objektivitas,

Etika, Integritas, dan Time

Budget Pressure terhadap

Kualitas Pemeriksaan pada

BPK Perwakilan Kalimantan

Timur. Organum: Jurnal

Saintifik Manajemen dan

Akuntansi, 3(2), 109-121. doi:

https://doi.org/10.35138/organu

m.v3i2.112
\end{abstract}

Journal Homepage:

ejournal.winayamukti.ac.id/inde x.php/Organum

Copyright:

(C) 2020. Published by Organum: Jurnal Saintifik Manajemen dan Akuntansi. Faculty of Economics and Business. Winaya Mukti University.

\begin{abstract}
This study aims to determine the effect of competence, objectivity, ethics, integrity, and time budget pressure on audit quality. Compliance with applicable accounting standards to maintain public trust in high state institutions in the Audit Board of the Republic of Indonesia is needed. This research was conducted at the Audit Board of the Republic of Indonesia, East Kalimantan Province Representative. Data were taken from distributed questionnaires, and produced 35 respondents using purposive sampling technique. The method of data analysis in this study used multiple linear regression. The results of this study indicated that integrity had a positive effect on audit quality. It showed that the higher the integrity of an auditor, the better the quality of the resulting inspection or auditing, while the variables of competence, objectivity, ethics, and time budget pressure had no effect on the quality of the resulting audit quality.
\end{abstract}

Keywords: Audit quality; competence; objectivity; ethics; integrity; time budget pressure.

Abstrak. Penelitian ini bertujuan untuk mengetahui pengaruh kompetensi, objektivitas, etika, integritas, dan time budget pressure terhadap kualitas pemeriksaan. Kesesuaian dengan standar akuntansi yang berlaku untuk menjaga kepercayaan masyarakat kepada lembaga tinggi negara terhadap Badan Pemeriksa Keuangan sangat diperlukan. Penelitian ini dilakukan pada Badan Pemeriksa Keuangan Republik Indonesia Perwakilan Provinsi Kalimantan Timur. Data diambil dari kuesioner yang dibagikan, dan menghasilkan 35 responden dengan menggunakan teknik purposive sampling. Metode analisis data dalam penelitian ini menggunakan regresi linear berganda. Hasil penelitian ini menunjukkan bahwa integritas berpengaruh positif terhadap kualitas pemeriksaan. Hal ini menunjukkan semakin tinggi integritas seorang pemeriksa maka akan semakin baik kualitas pemeriksaan yang dihasilkan, sedangkan variabel kompetensi, objektivitas, etika, dan time budget pressure tidak berpengaruh terhadap kualitas pemeriksaan yang dihasilkan.

Kata Kunci: Kualitas pemeriksaan; kompetensi; objektivitas; etika; integritas; time budget pressure.

\section{Pendahuluan}

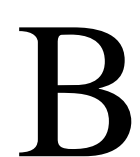
adan Pemeriksa Keuangan (BPK) melakukan pemeriksaan atas laporan keuangan pemerintah untuk memberikan opini mengenai kewajaran informasi keuangan yang disajikan dalam laporan keuangan pemerintah. Kewajaran informasi keuangan ini didasarkan pada kriteria kesesuaian dengan standar akuntansi 
pemerintahan, kecukupan pengungkapan, kepatuhan terhadap peraturan perundangundangan, dan efektivitas sistem pengendalian intern (Badan Pemeriksa Keuangan Republik Indonesia, 2004).

Terdapat kasus di tahun 2019 bahwa komisi pemberantasan korupsi menetapkan Rizal Djalil sebagai tersangka suap proyek sistem penyediaan air minum dari anggota Badan Pemeriksa Keuangan, Rizal diduga menerima suap sebesar SG\$100,000 atau sekitar Rp1 miliar untuk memuluskan proyek tersebut (Ramadhan, 2019).

Kasus pelanggaran yang dilakukan oknum BPK secara tidak langsung menurunkan kepercayaan terhadap publik terkait dengan kualitas pemeriksaan yang dihasilkan. Kasus pelanggaran yang dilakukan oknum BPK merupakan kebohongan terhadap publik terkait dengan opini pemeriksaan yang dihasilkan (Layli \& Arifin, 2020).

Kualitas hasil pemeriksaan merupakan hasil akhir dari laporan pemeriksaan yang mana laporan tersebut dapat dipertanggungjawabkan sesuai dengan standar yang berlaku. Dalam melaksanakan pemeriksaan atas laporan keuangan pemerintah, para pemeriksa diharapkan telah memenuhi standar yang sudah ditetapkan (Badan Pemeriksa Keuangan Republik Indonesia, 2017:107).

Pemeriksa yang melaksanakan pemeriksaan diharapkan memiliki kompetensi dan pengetahuan umum, keterampilan berinteraksi dan berkomunikasi yang baik. Badan Pemeriksa Keuangan telah menerbitkan kode etik pemeriksaan pengelolaan dan tanggung jawab keuangan negara sebagai acuan perilaku pemeriksa dalam menjalankan tugas pemeriksaan.

Pemeriksa yang memiliki sikap profesional akan melaksanakan pekerjaan dengan sikap objektif, memiliki etika yang baik, berintegritas tinggi, serta memanfaatkan waktu yang diberikan dengan baik, hal ini akan memengaruhi kualitas pemeriksaan yang dihasilkan. Objektivitas dari seorang pemeriksa merupakan sikap yang memberikan nilai lebih atas pekerjaan yang telah diberikan, landasan objektivitas dalam pemeriksaan adalah tidak berpihak, dapat dipercaya, adil dalam memutuskan, baik secara intelektual, tidak ada kepentingan pribadi, dan tidak berada di bawah pengaruh lain. Selain itu, integritas yang baik menjadi landasan bagi pengakuan profesional pemeriksa yang merupakan kualitas yang dapat menjadikan timbulnya kepercayaan di masyarakat.

Hal yang paling sering dijadikan alasan dalam kinerja kurang baik salah satunya adalah time budget pressure, yaitu di mana keadaan pemeriksa dituntut untuk melaksanakan pemeriksaan dengan batasan waktu yang sudah ditetapkan untuk menghasilkan laporan pemeriksaan. Laporan hasil pemeriksaan atas laporan keuangan Pemerintah Daerah disampaikan oleh BPK kepada Dewan Perwakilan Rakyat Daerah (DPRD) paling lambat 2 bulan setelah menerima laporan keuangan dari Pemerintah Daerah (Undang-undang Nomor 15 Tentang Pemeriksaan Pengelolaan dan Tanggung Jawab Keuangan Negara, 2004:7).

\section{Kajian Literatur}

\section{Agency Theory}

Dalam teori agensi menjelaskan bahwa hubungan keagenan merupakan sebuah kontrak, di mana principal untuk memerintahkan orang lain (agent) dalam melakukan suatu jasa atas nama principal serta memberikan kepercayaan pada agent untuk membuat keputusan atau mengelolanya dengan baik (Jensen \& Meckling, 1976).

Hubungan antara teori keagenan terhadap kualitas pemeriksaan sangatlah erat, sebab teori keagenan akan memecahkan masalah asimetri antara principal dan agent dengan memerlukan pihak ketiga yang independen, sehingga laporan keuangan yang dihasilkan mendapat kewajaran, maka berkaca dari 
permasalahan tersebut kualitas pemeriksaan yang dihasilkan pemeriksa sangat diperlukan dalam pengambilan keputusan.

\section{Teori Behavioural Accounting}

Teori behavioural accounting merupakan cabang akuntansi yang mempelajari hubungan antara perilaku manusia dengan sistem akuntansi. Akuntansi keperilakuan merupakan penghubung antara akuntansi dan ilmu sosial yang berhubungan dengan bagaimana perilaku manusia memengaruhi informasi akuntansi dan keputusan-keputusan organisasi serta bagaimana informasi akuntansi memengaruhi keputusan-keputusan organisasi dan perilaku manusia (Supriyono, 2018).

Ruang lingkup akuntansi

keperilakuan dalam penelitian ini yaitu bagaimana tugas yang dihadapi oleh pemeriksa dapat memengaruhi pertimbangan serta dalam pengambilan keputusan pemeriksaan.

\section{Kompetensi}

Kompetensi tidak hanya diukur secara kuantitatif yaitu berapa lama pengalaman pemeriksaan, hal tersebut tidak dapat menggambarkan secara akurat jenis pengalaman yang dimiliki pemeriksa. Pemeriksa yang telah mendapatkan tugas untuk melaksanakan pemeriksaan menurut standar pemeriksaan harus secara kolektif atau dengan indikator memiliki kompetensi pengetahuan umum, keterampilan berkomunikasi, dan pengetahuan khusus (Badan Pemeriksa Keuangan Republik Indonesia, 2017:36).

Kompetensi berupa keterampilan dan pengetahuan yang didapatkan dari lingkungan sosial, lingkungan kerja yang diserap, dan pelatihan, hal ini digunakan sebagai alat untuk menciptakan nilai dengan cara melaksanakan tugas dengan baik (Hartanto, 2009).

\section{Objektivitas}

Objektivitas merupakan kualitas yang memberikan nilai lebih atas pekerjaan yang telah diberikan, landasan objektivitas dalam pemeriksaan adalah tidak berpihak, dapat dipercaya, adil dalam memutuskan, baik secara intelektual, tidak ada kepentingan pribadi, dan tidak berada di bawah pengaruh lain (Bachtiar, 2019).

Pengukuran objektivitas yang tidak bersifat personal, akan menghasilkan hasil yang baik, artinya pemeriksa tidak ada benturan kepentingan merujuk pada realitas eksternal yang independen terhadap entitas yang diperiksa. Jadi objektivitas merupakan hal penting yang dimiliki pemeriksa agar tidak berpihak kepada entitas, terbebas dari benturan kepentingan serta tidak dapat dipengaruhi oleh pihak lain.

\section{Etika}

Berdasarkan ketentuan standar pemeriksaan keuangan negara (Badan Pemeriksa Keuangan Republik Indonesia, 2017:29), etika anggota BPK yaitu pemeriksa diwajibkan menerapkan pemeriksaan sesuai dengan prinsip etika pemeriksaan. Hal ini dimaksudkan untuk mencapai harapan publik serta transparansi dalam melaksanakan pemeriksaan laporan keuangan negara.

Melakukan pemeriksaan dengan menerapkan etika yang sudah ditentukan akan meningkatkan kualitas dan hasil pekerjaan pemeriksaan yang lebih berkualitas sehingga kepercayaan masyarakat meningkat.

\section{Integritas}

Berdasarkan ketentuan standar pemeriksaan keuangan negara (Badan Pemeriksa Keuangan Republik Indonesia, 2017:33-34), integritas diaplikasikan dalam sikap dapat dipercaya, tidak ada benturan kepentingan, memiliki prinsip yang tegas dalam pengambilan keputusan. Ancaman terhadap integritas dapat terjadi dalam hal meminta atau 
menerima uang, barang, serta fasilitas yang bukan haknya.

Integritas menjadi landasan karakter sebagai pengakuan bagi pemeriksa dan merupakan kualitas yang dapat menjadikan timbulnya kepercayaan di masyarakat.

\section{Time Budget Pressure}

Time budget pressure keadaan di mana pemeriksa diwajibkan untuk melakukan efisiensi terhadap anggaran waktu yang sudah diberikan dan disusun guna tercapainya hasil yang baik (Nirmala \& Cahyonowati, 2013). Time budget pressure dalam hal ini diartikan sebagai waktu yang diberikan untuk menyelesaikan tugas. Hal yang paling sering dijadikan alasan dalam kinerja kurang baik adalah time budget pressure (Supriyono, 2018).

\section{Kualitas Pemeriksaan}

Kualitas hasil pemeriksaan merupakan hasil akhir dari laporan pemeriksaan yang dapat dipertanggungjawabkan sesuai dengan standar yang telah ditetapkan. Pemeriksa yang melaksanakan pemeriksaan atas laporan keuangan pemerintah diwajibkan memenuhi standar pemeriksaan yang telah ditetapkan oleh Badan Pemeriksaan Keuangan Republik Indonesia (Badan Pemeriksa Keuangan Republik Indonesia, 2017:8).

Berdasarkan uraian tersebut, seorang pemeriksa memiliki posisi yang strategis baik di mata manajemen maupun di mata entitas. Selain itu, pemakai laporan keuangan memiliki harapan serta kepercayaan tinggi kepada pemeriksa terhadap laporan hasil pemeriksaan. Untuk dapat memenuhi kualitas pemeriksaan yang baik maka pemeriksa dalam menjalankan tugasnya diharapkan memiliki kompetensi yang baik, tidak berpihak, berpedoman pada kode etik yang sudah ditentukan sesuai standar profesi dan standar akuntansi keuangan yang berlaku di Indonesia. Berikut dapat digambarkan model penelitian yang digunakan dalam penelitian ini:

Gambar 1. Model Penelitian

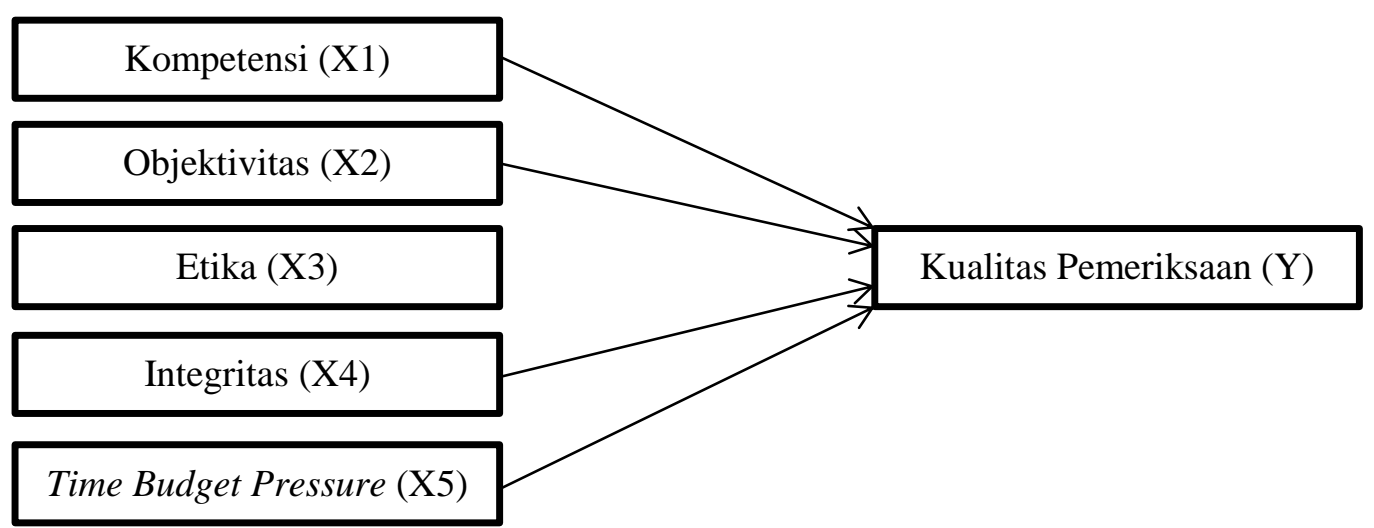

\section{Hipotesis Penelitian}

Berdasarkan teori yang terkait dengan kualitas pemeriksaan maka dirumuskan hipotesis sebagai berikut.

$\mathrm{H} 1$ : Kompetensi berpengaruh positif terhadap kualitas pemeriksaan.

$\mathrm{H} 2$ : Objektivitas berpengaruh positif terhadap kualitas pemeriksaan.
H3: Etika berpengaruh positif terhadap kualitas pemeriksaan.

H4: Integritas berpengaruh positif terhadap kualitas pemeriksaan.

H5: Time budget pressure berpengaruh negatif terhadap kualitas pemeriksaan. 


\section{Metode Penelitian}

Jenis penelitian ini adalah kuantitatif dengan data primer untuk menganalisis pengaruh kompetensi, objektivitas, etika, integritas, time budget pressure terhadap kualitas pemeriksaan di Badan Pemeriksa Keuangan (BPK) Perwakilan Provinsi Kalimantan Timur. Populasi dalam penelitian ini adalah seluruh pemeriksa pada Badan Pemeriksa Keuangan Perwakilan Provinsi Kalimantan Timur yaitu sebanyak 43 responden.

Metode untuk pemilihan sampel yang akan digunakan yaitu metode sensus. Metode sensus merupakan teknik penentuan sampel dengan anggota populasi digunakan menjadi sampel (Sugiyono, 2010). Data yang digunakan kembali kepada peneliti yaitu sebanyak 36 responden.

Pertanyaan dalam kuesioner untuk masing-masing variabel diukur dengan skala Likert. Skala Likert merupakan suatu skala yang digunakan untuk mengukur sikap, pendapat, dan persepsi seseorang atau sekelompok orang tentang fenomen sosial, dan poin 1 diberikan untuk jawaban yang paling rendah, sedangkan semakin mengarah ke poin 5 menunjukkan yang paling tinggi.

Teknik analisis dalam penelitian ini yaitu dengan menggunakan metode analisis regresi linier berganda meliputi statistik deskriptif, uji kualitas data, uji asumsi klasik, uji model, dan uji hipotesis. Adapun persamaan regresi linier berganda sebagai berikut.

$\mathrm{Y}=\mathrm{a}+\mathrm{b} 1 \mathrm{X}_{1}+\mathrm{b} 2 \mathrm{X}_{2}+\mathrm{b} 3 \mathrm{X}_{3}+\mathrm{b} 4 \mathrm{X}_{4}+$ $\mathrm{b} 5 \mathrm{X}_{5}+\mathrm{e}$

Keterangan:

$$
\begin{array}{ll}
\mathrm{Y} & =\text { Kualitas Pemeriksaan } \\
\mathrm{a} & =\text { Konstanta } \\
\mathrm{X}_{1} & =\text { Kompetensi } \\
\mathrm{X}_{2} & =\text { Objektivitas } \\
\mathrm{X}_{3} & =\text { Etika } \\
\mathrm{X}_{4} & =\text { Integritas } \\
\mathrm{X}_{5} & =\text { Time Budget Pressure } \\
\mathrm{b} 1 & =\text { Koefisien Regresi Kompetensi }
\end{array}
$$

b2 = Koefisien Regresi Objektivitas

b3 = Koefisien Regresi Etika

b4 = Koefisien Regresi Integritas

b5 = Koefisien Regresi Time Budget

Pressure

e $\quad=$ Standar Error

\section{Hasil dan Pembahasan}

Hasil

\section{Karakteristik Responden}

Berdasarkan jawaban dari 43 responden maka diperoleh deskripsi karakteristik responden mengenai umur pemeriksa, jenis kelamin, pendidikan terakhir, dan jabatan. Responden berdasarkan umur pemeriksa responden yang tertinggi berpartisipasi dalam penelitian ini mayoritas adalah dengan umur 31-35 tahun sebanyak 16 responden dengan persentase sebesar $44 \%$. Sedangkan, umur pemeriksa terendah hanya sebanyak 10 responden dengan persentase $28 \%$, sisanya responden dengan umur di atas 35 tahun dengan persentase $28 \%$, responden berdasarkan jenis kelamin dengan persentase sebesar $64 \%$.

Responden berdasarkan pendidikan terakhir yang berpartisipasi dalam penelitian ini terbanyak adalah S1 dengan 27 responden dengan persentase sebesar $75 \%$, responden berdasarkan jabatan pemeriksa, responden yang berpartisipasi dalam penelitian ini terbanyak adalah anggota tim dengan 30 responden dengan persentase sebesar $83 \%$, sedangkan ketua tim hanya sebanyak 6 responden dengan persentase $17 \%$.

\section{Statistik Deskriptif}

Statistik deskriptif digunakan untuk memberikan gambaran atau deskripsi suatu data yang dilihat dari jumlah responden $(\mathrm{N})$, minimum, maksimum, rata-rata (mean) dan standar deviasi. Tabel 1 menggambarkan statistik deskriptif dari variabel kompetensi, objektivitas, etika, integritas, dan time budget pressure. 
Tabel 1. Statistik Deskriptif

\begin{tabular}{lccccc}
\hline \multicolumn{1}{c}{ Variabel } & N & Minimum & Maksimum & Mean & $\begin{array}{c}\text { Std. } \\
\text { Deviation }\end{array}$ \\
\hline Kompetensi (X1) & 36 & 30 & 45 & 39,06 & 4,147 \\
\hline Objektivitas (X2) & 36 & 22 & 30 & 26,64 & 2,748 \\
\hline Etika (X3) & 36 & 33 & 45 & 40,31 & 4,055 \\
\hline Integritas (X4) & 36 & 50 & 70 & 62,22 & 6,604 \\
\hline Time Budget Pressure (X5) & 36 & 16 & 30 & 24,03 & 3,813 \\
\hline Kualitas Pemeriksaan (Y) & 36 & 32 & 45 & 39,67 & 4,421 \\
\hline
\end{tabular}

Berdasarkan hasil tabel analisis statistik deskriptif pada Tabel 1, variabel kompetensi memiliki jumlah 36 responden dengan jawaban terendah (minimum) sebesar 34, nilai jawaban terbesar (maksimum) dari responden sebesar 50, nilai rata-rata (mean) dari responden sebesar 42,94 dan nilai standar deviasi dari responden sebesar 4,269.

Hasil analisis deskriptif variabel objektivitas memiliki jumlah 36 responden dengan jawaban terendah (minimum) sebesar 22, jawaban terbesar (maksimum) dari responden sebesar 30, nilai rata-rata (mean) dari responden sebesar 26,64 dan nilai standar dari responden deviasi sebesar 2,748. Hasil analisis deskriptif variabel etika memiliki jumlah 36 responden dengan jawaban terendah (minimum) sebesar 37, jawaban terbesar (maksimum) dari responden sebesar 50, nilai rata-rata (mean) dari responden sebesar 44,72 dan nilai standar deviasi dari responden sebesar 4,280.

Hasil analisis deskriptif variabel integritas memiliki jumlah 36 responden dengan jawaban terendah (minimum) sebesar 50, jawaban terbesar (maksimum) dari responden sebesar 70 , nilai rata-rata (mean) dari responden sebesar 62,22 dan nilai standar deviasi dari responden sebesar 6,604.

Hasil analisis deskriptif variabel time budget pressure memiliki jumlah 36 responden dengan jawaban terendah (minimum) sebesar 16, jawaban terbesar (maksimum) dari responden sebesar 30, nilai rata-rata (mean) dari responden sebesar 24,03 dan nilai standar deviasi dari responden sebesar 3,813.

Hasil analisis deskriptif variabel kualitas pemeriksaan memiliki jumlah 36 responden dengan jawaban terendah (minimum) sebesar 32, nilai jawaban terbesar (maksimum) dari responden sebesar 45, nilai rata-rata (mean) dari responden sebesar 39,67 dan nilai standar deviasi dari responden sebesar 4,421.

\section{Uji Validitas}

Uji validitas digunakan untuk mengukur valid tidaknya suatu kuesioner. $\mathrm{R}$ table $=\mathrm{df}$

$$
\begin{aligned}
\text { Df } & =\mathrm{N}-2 \\
& =36-2 \\
& =34 \text { (nilai } \mathrm{r} \text { tabel adalah } \mathbf{0 , 3 2 9}) \\
& \text { Dari pengujian masing-masing }
\end{aligned}
$$
variabel kompetensi, objektivitas, etika, integritas, dan time budget pressure didapatkan hasil valid semua item pertanyaan dengan nilai $\mathrm{r}$ hitung lebih besar dari $r$ tabel dan nilai positif.

\section{Uji Reliabilitas}

Uji reliabilitas digunakan untuk melihat konsistensi jawaban. Pengujian ini pada sistem SPSS menggunakan uji statistik Cronbach's Alpha, kriteria reliabilitas alpha dikatakan reliabel jika memberikan nilai Cronbach's Alpha $(\alpha)>$ 0,70 (Ghozali, 2018). 
Tabel 2. Uji Reliabilitas

\begin{tabular}{lccc}
\hline \multicolumn{1}{c}{ Variabel } & $\begin{array}{c}\text { Cronbach's } \\
\text { Alpha }\end{array}$ & Nilai Kritis & Keterangan \\
\hline Kompetensi & 0,864 & 0,70 & Reliabel \\
\hline Objektivitas & 0,825 & 0,70 & Reliabel \\
\hline Etika & 0,878 & 0,70 & Reliabel \\
\hline Integritas & 0,934 & 0,70 & Reliabel \\
\hline Time Budget Pressure & 0,795 & 0,70 & Reliabel \\
\hline Kualitas Pemeriksaan & 0,904 & 0,70 & Reliabel \\
\hline
\end{tabular}

Berdasarkan hasil tabel uji reliabilitas pada Tabel 2 dapat disimpulkan bahwa pertanyaan yang digunakan adalah reliabel karena nilai Cronbach's Alpha $>0,70$.

\section{Uji Normalitas}

Uji normalitas untuk mengetahui model regresi, variabel dependen dan independen keduanya berdistribusi normal atau tidak.

Tabel 3. Uji Normalitas

\begin{tabular}{cccc}
\hline Variabel & $\begin{array}{c}\mathbf{N} \\
\text { (Jumlah Sampel) }\end{array}$ & Signifikansi & Keterangan \\
\hline Unstandardized Residual & 36 & 0,209 & Berdistribusi Normal \\
\hline
\end{tabular}

Hasil uji normalitas dengan OneSample Kolmogorov-Smirnov Test dengan 36 sampel menunjukkan bahwa nilai signifikansi sebesar 0,209 yang menunjukkan bahwa nilai signifikansi Unstandardized Residual lebih besar dari $0,05(0,209>0,05)$.

\section{Uji Multikolinearitas}

Berdasarkan

hasil

uji multikolinearitas diketahui bahwa hasil dari uji multikolinearitas menunjukan nilai tolerance $>0,10$ dan nilai dari VIF < 10, maka dapat disimpulkan bahwa model regresi yang diajukan tidak terjadi gejala multikolinearitas.

Tabel 4. Uji Multikolinearitas

\begin{tabular}{lccc}
\hline \multicolumn{1}{c}{ Variabel } & Tolerance & $\begin{array}{c}\text { VIF } \\
\text { (Variance } \\
\text { Inflation Factor })\end{array}$ & Keterangan \\
\hline Kompetensi & 0,399 & 2,506 & Tidak terjadi Multikolonieritas \\
\hline Objektivitas & 0,298 & 3,352 & Tidak terjadi Multikolonieritas \\
\hline Etika & 0,208 & 4,818 & Tidak terjadi Multikolonieritas \\
\hline Integritas & 0,166 & 6,035 & Tidak terjadi Multikolonieritas \\
\hline Time Budget Pressure & 0,611 & 1,638 & Tidak terjadi Multikolonieritas \\
\hline
\end{tabular}

\section{Uji Heteroskedastisitas}

Uji heteroskedastisitas bertujuan untuk menguji apakah nilai model regresi terjadi ketidaksamaan variance residual satu pengamatan ke pengamatan yang lain (Ghozali, 2018). Jika probabilitas signifikan masing-masing variabel independen $>0.05$.

Tabel 5. Uji Heteroskedastisitas

\begin{tabular}{lcc}
\hline \multicolumn{1}{c}{ Variabel } & Signifikansi & Keterangan \\
\hline Kompetensi & 0,580 & Tidak Ada gejala heteroskedastisitas \\
\hline Objektivitas & 0,090 & Tidak Ada gejala heteroskedastisitas \\
\hline
\end{tabular}




\begin{tabular}{lll}
\hline Etika & 0,587 & Tidak Ada gejala heteroskedastisitas \\
\hline Integritas & 0,577 & Tidak Ada gejala heteroskedastisitas \\
\hline Time Budget Pressure & 0,188 & Tidak Ada gejala heteroskedastisitas \\
\hline
\end{tabular}

Berdasarkan hasil uji heteroskedastisitas pada Tabel 5 menunjukkan bahwa tidak ada gangguan heteroskedastisitas di mana nilai signifikan (sig.) lebih dari 0,05 (p > $0,05)$.

Tabel 6. Uji F

\begin{tabular}{cccccc}
\hline Model & Sum of Squares & df & Mean Square & F & Sig. \\
\hline Regression & 466,330 & 5 & 93,266 & 12,858 & 0,123 \\
\hline Residual & 210,356 & 29 & 7,254 & & \\
\hline Total & 676,686 & 34 & & & \\
\hline
\end{tabular}

Hasi uji $\mathrm{F}=12,858$ tersebut dengan signifikansi $0,000<0,05, \quad$ secara bersama-sama kompetensi, objektivitas, etika, integritas, dan time budget pressure secara bersama-sama tidak berpengaruh signifikan terhadap kualitas pemeriksaan.

\section{Uji Koefisien Determinasi $\left(\mathbf{R}^{\mathbf{2}}\right)$}

Determinasi $R^{2}$ pada intinya mengukur seberapa jauh kemampuan model dalam menerangkan atau menjelaskan variabel dependen.

\section{Tabel 7. Uji Koefisien Determinasi $\left(\mathbf{R}^{2}\right)$}

\begin{tabular}{ccccc}
\hline Model & R & R Square & Adjusted $R$ Square & Std. Error of the Estimate \\
\hline 1 & 0,830 & 0,689 & 0,636 & 2,69326
\end{tabular}

Besarnya pengaruh secara bersamasama kompetensi, objektivitas, etika, integritas, dan time buget pressure berpengaruh signifikan terhadap kualitas pemeriksaan (Adjusted $R$ Square) adalah 0,636 atau $63,6 \%$ dan sisanya sebesar $36,4 \%$ dipengaruhi oleh variabel lain yang tidak diteliti.

\section{Uji Parsial (Uji t)}

Berikut hasil analisis pengaruh masing-masing variabel bebas (independen) secara parsial terhadap variabel terikat (dependen) sebagai berikut:

\section{Tabel 8. Hasil Uji Parsial (Uji t)}

\begin{tabular}{lrrrrr}
\hline \multirow{1}{*}{ Model } & \multicolumn{2}{c}{$\begin{array}{c}\text { Unstandardized } \\
\text { Coefficients }\end{array}$} & $\begin{array}{c}\text { Standardized } \\
\text { Coefficients }\end{array}$ & t & Sig. \\
\cline { 2 - 4 } & $\mathbf{B}$ & $\begin{array}{c}\text { Std. } \\
\text { Error }\end{array}$ & Beta & & \\
\hline (Constant) & 10.110 & 5.238 & & 1.930 & .063 \\
\hline Kompetensi (X1) & -.037 & .188 & -.035 & -.197 & .845 \\
\hline Objektivitas (X2) & .115 & .319 & .070 & .361 & .721 \\
\hline Etika (X3) & -.349 & .255 & -.320 & -1.366 & .182 \\
\hline Integritas (X4) & .800 & .181 & 1.198 & 4.429 & .000 \\
\hline Time Budget & -.312 & .166 & -.252 & -1.876 & .071 \\
Pressure (X5) & & & & & \\
\hline
\end{tabular}




\section{Pembahasan}

\section{Pengaruh Kompetensi terhadap Kualitas Pemeriksaan}

Hasil pengujian analisis regresi berganda menunjukkan bahwa nilai koefisien regresi variabel kompetensi dengan arah negatif sebesar -0,037 dengan nilai t hitung yang lebih kecil dari nilai $\mathrm{t}$ tabel $(-0,197>1,69913)$ nilai signifikan $(0,071>0,05)$, maka dapat disimpulkan kompetensi (X1) tidak berpengaruh terhadap kualitas pemeriksaan, sehingga dapat dinyatakan H1 ditolak.

Hasil penelitian ini menyatakan bahwa kompetensi tidak berpengaruh terhadap kualitas pemeriksaan. Berdasarkan dari hasil regresi nilai minus (-) yang terdapat pada $t$ hitung yang menunjukkan hubungan yang berlawanan arah, di mana setiap terjadinya penurunan terhadap kompetensi akan berdampak terhadap penurunan kualitas pemeriksaan, demikian sebaliknya.

Hasil penelitian ini searah dengan penelitian yang dilakukan oleh (Ilham, Suarthana, \& Surono, 2018), (Agustina, Sudarna, \& Ludigdo, 2014) bahwa kompetensi tidak berpengaruh terhadap kualitas pemeriksaan. Hal ini dapat dikatakan kompetensi pemeriksa yang tinggi atau rendah belum tentu akan memengaruhi kualitas pemeriksaan.

Berdasarkan hasil penelitian tersebut, fenomen yang terjadi dalam penelitian ini banyaknya responden yang dimayoritasi oleh anggota tim diketahui sebesar $83 \%$ yang artinya terdapat gap sebesar $17 \%$ dengan ketua tim, serta pemeriksa dengan berpendidikan S1 sebesar $75 \%$ yang artinya terdapat gap $25 \%$ hal ini menggambarkan belum meratanya pemahaman keikutsertaan dalam mengikuti pelatihan teknis, sehingga hal ini diharapkan menjadi bahan evaluasi untuk dapat meningkatkan kualitas pemeriksaan.

\section{Pengaruh Objektivitas terhadap Kualitas Pemeriksaan}

Hasil pengujian analisis regresi berganda bahwa nilai koefisien regresi variabel objektivitas dengan arah positif sebesar $0,115 \mathrm{t}$ hitung yang lebih kecil dari nilai $t$ tabel $(0,361>1,69913)$ nilai signifikan $(0,721>0,05)$, maka dapat disimpulkan objektivitas (X2) tidak berpengaruh terhadap kualitas pemeriksaan, sehingga dapat dinyatakan $\mathrm{H} 2$ ditolak.

Objektivitas merupakan kualitas yang memberikan nilai lebih atas pekerjaan yang telah diberikan, landasan objektivitas dalam pemeriksaan adalah tidak berpihak, dapat dipercaya, adil dalam memutuskan, baik secara intelektual, tidak ada kepentingan pribadi, dan tidak berada di bawah pengaruh lain (Bachtiar, 2019).

Hasil dalam penelitian ini menyatakan bahwa objektivitas tidak berpengaruh terhadap kualitas pemeriksaan. Berdasarkan dari hasil regresi nilai positif (+) yang terdapat pada $t$ hitung yang menunjukkan hubungan yang searah, dan setiap terjadinya peningkatan terhadap objektivitas akan berdampak terhadap kualitas pemeriksaan, demikian sebaliknya. Hasil penelitian ini searah dengan penelitian yang dilakukan oleh (Susilo \& Widyastuti, 2015), objektivitas tidak berpengaruh terhadap kualitas pemeriksaan.

Objektivitas tidak berpengaruh terhadap kualitas pemeriksaan terdapat adanya pertanyaan yang sensitif sehingga responden menjawab dengan ragu-ragu dan menyebabkan bias dalam jawaban responden.

\section{Pengaruh Etika terhadap Kualitas Pemeriksaan}

Hasil pengujian analisis regresi berganda menunjukkan bahwa nilai koefisien regresi variabel etika dengan arah negatif sebesar $-0,349$ dengan nilai $t$ hitung yang lebih kecil dari nilai t tabel ($1,366>1,69913)$ dan besarnya nilai 
signifikan $(0,182>0,05)$, maka dapat disimpulkan etika (X3) tidak berpengaruh terhadap kualitas pemeriksaan, sehingga dapat dinyatakan H3 ditolak. Hasil penelitian ini menyatakan bahwa etika tidak berpengaruh terhadap kualitas pemeriksaan. Berdasarkan hasil regresi nilai minus (-) yang terdapat pada $\mathrm{t}$ hitung menunjukkan hubungan yang berlawanan arah, serta setiap terjadinya penurunan terhadap etika akan berdampak terhadap penurunan kualitas pemeriksaan, demikian sebaliknya. Hasil penelitian ini searah dengan penelitian yang dilakukan oleh (Syafitri, 2014), etika tidak berpengaruh terhadap kualitas pemeriksaan.

Hal ini mengidentifikasikan adanya beragam persepsi dari etika dan tanggung jawab responden dalam melakukan pemeriksaan, sehingga seorang pemeriksa belum sepenuhnya melakukan tahap-tahap pemeriksaan laporan keuangan sesuai standar teknis yang telah ditetapkan sesuai kode etik BPK.

\section{Pengaruh Integritas terhadap Kualitas Pemeriksaan}

Hasil pengujian analisis regresi berganda menunjukkan nilai koefisien regresi variabel integritas dengan arah positif sebesar 0,800 dengan nilai thitung yang lebih besar dari nilai t tabel $(4,429>$ 1,69913) dan kecilnya nilai signifikan $(0,000>0,05$, maka dapat disimpulkan integritas (X4) berpengaruh positif terhadap kualitas pemeriksaan, sehingga dapat dinyatakan $\mathrm{H} 4$ diterima.

Integritas diaplikasikan dalam sikap dapat dipercaya, tidak ada benturan kepentingan, memiliki prinsip yang tegas dalam pengambilan keputusan. Ancaman terhadap integritas dapat terjadi dalam hal meminta atau menerima uang, barang, serta fasilitas yang bukan haknya.

Hasil penelitian ini menyatakan bahwa integritas berpengaruh terhadap kualitas pemeriksaan. Berdasarkan hasil regresi nilai positif $(+)$ yang terdapat pada $t$ hitung yang menunjukkan hubungan yang searah, dan setiap terjadinya peningkatan terhadap integritas akan berdampak terhadap peningkatan kualitas pemeriksaan, demikian sebaliknya.

Hasil penelitian ini searah dengan penelitian yang dilakukan oleh (Faizah \& Zuhdi, 2013), dan (Arianti, Sujana, \& Adiputra, 2014) membuktikan bahwa integritas berpengaruh positif terhadap kualitas pemeriksaan. Hal ini menunjukkan bahwa pemeriksa tidak mempertimbangkan keadaan seseorang sekelompok orang atau suatu unit organisasi untuk membenarkan perbuatan melanggar ketentuan yang berlaku artinya tetap dalam pendirian.

Hasil ini menggambarkan seorang pemeriksa betapa pentingnya sebuah kejujuran dan keyakinan dalam membentuk karakter moral yang baik. Karakter moral yang harus dimiliki seorang pemeriksa dalam menjalankan kinerjanya sebagai pemeriksa laporan keuangan dapat membantu memperoleh kualitas pemeriksaan yang baik, sehingga menjadikan timbulnya kepercayaan di masyarakat terhadap pemeriksa di Badan Pemeriksa Keuangan Perwakilan Provinsi Kalimantan Timur.

\section{Pengaruh Time Budget Pressure terhadap Kualitas Pemeriksaan}

Hasil pengujian analisis regresi berganda bahwa nilai koefisien regresi variabel time budget pressure dengan arah negatif sebesar $-0,312$ dengan nilai $t$ hitung yang lebih kecil dari nilai t tabel ($1,876>1,69913)$ dan besarnya nilai signifikan $(0,071>0,05)$, maka dapat disimpulkan time budget pressure (X5) tidak berpengaruh terhadap kualitas pemeriksaan, sehingga dapat dinyatakan H5 diterima.

Time budget pressure keadaan di mana pemeriksa diwajibkan untuk melakukan efisiensi terhadap anggaran waktu yang sudah diberikan dan disusun dimaksudkan untuk tercapainya hasil yang baik (Nirmala \& Cahyonowati, 2013). Time budget pressure dalam hal ini diartikan sebagai waktu yang 
diberikan untuk menyelesaikan tugas. Hasil penelitian ini menyatakan bahwa time budget pressure tidak berpengaruh terhadap kualitas pemeriksaan.

Berdasarkan dari hasil regresi nilai minus (-) yang terdapat pada $\mathrm{t}$ hitung yang menunjukkan hubungan yang searah, di mana setiap terjadinya penurunan terhadap time budget pressure akan berdampak terhadap penurunan kualitas pemeriksaan, demikian sebaliknya.

Hasil penelitian ini searah dengan penelitian yang dilakukan oleh (Pikirang, Sabijono, \& Wokas, 2017), (Sari \& Lestari, 2018), dan (Rizal \& Liyundira, 2016) time budget pressure tidak berpengaruh terhadap kualitas pemeriksaan. Hasil ini menggambarkan tanggapan responden mengindikasikan bahwa pemeriksa mayoritas merasakan time budget pressure dalam penugasannya. Penetapan waktu yang kurang menyebabkan penurunan tingkat pendeteksian salah saji dalam laporan keuangan, kurangnya pemahaman atas penjelasan dari entitas serta pemberian data yang lama menjadi faktor pemeriksa mengalami tekanan waktu.

\section{Kesimpulan}

Kompetensi tidak berpengaruh terhadap kualitas pemeriksaan. Hal ini berkaitan dengan latar belakang pendidikan pemeriksa, bukan hanya pengetahuan tentang akuntansi saja melainkan diperlukan pengetahuan tentang teknik sipil, pertanian, kesehatan, hal ini bertujuan untuk memudahkan para pemeriksa untuk menjalankan tugasnya dengan baik.

Objektivitas tidak berpengaruh terhadap kualitas pemeriksaan. Hasil ini membuktikan adanya hubungan yang tidak searah dengan kualitas pemeriksaan seorang pemeriksa dalam menjalankan tugasnya, hal ini dapat terjadi seorang pemeriksa masih terpengaruh terhadap kepentingan, atau pengaruh tekanan oleh entitas.
Etika tidak berpengaruh terhadap kualitas pemeriksaan. Hasil ini adanya beragam persepsi dari etika dan tanggung jawab responden, sehingga terdapat pemeriksa yang belum sepenuhnya melakukan tahap-tahap pemeriksaan laporan keuangan sesuai standar teknis yang telah ditetapkan sesuai kode etik BPK.

Integritas berpengaruh positif terhadap kualitas pemeriksaan. Artinya semakin tinggi tingkat integritas yang dimiliki pemeriksa, maka kualitas pemeriksaaan yang dihasilkan akan semakin baik. Time budget pressure tidak berpengaruh terhadap kualitas pemeriksaan. Hasil ini membuktikan adanya hubungan searah dengan kualitas pemeriksaan, yang menyebabkan menurunnya efektivitas dan efesiensi kegiatan pemeriksaan.

\section{Daftar Pustaka}

Agustina, D., Sudarna, M., \& Ludigdo, U. (2014). Pengaruh Kompetensi, Independensi, dan Ukuran Auditee Terhadap Kualitas. El Muhasaba: Jurnal Akuntansi, 5(2), 226-239. doi:

https://doi.org/10.18860/em.v5i2.28 $\underline{61}$

Arianti, K. P., Sujana, E., \& Adiputra, M. P. (2014). Pengaruh Integritas, Objektivitas dan Akuntabilitas Terhadap Kualitas Audit (Studi pada Inspektorat Kabupaten Buleleng). JIMAT (Jurnal Ilmiah Mahasiswa Akuntansi) Undiksha, 2(1). Diakses dari https://ejournal.undiksha.ac.id/inde x.php/S1ak/article/view/2410/2087

Bachtiar, N. (2019). Akuntansi Dasar Buku Pintar Untuk Pemula. Yogyakarta: CV. Budi Utama.

Badan Pemeriksa Keuangan Republik Indonesia. (2004). Undang-Undang Nomor 15 Tentang Pemeriksaan 
Pengelolaan dan Tanggung Jawab Keuangan Negara. Jakarta: Badan Pemeriksaan Keuangan Republik Indonesia. Diakses dari https://www.bpk.go.id/assets/files/st orage/2013/12/file_storage_138615 8654.pdf

Badan Pemeriksa Keuangan Republik Indonesia. (2017). Standar Pemeriksaan Keuangan Negara (SPKN). Jakarta: Badan Pemeriksa Keuangan Republik Indonesia. Diakses dari https://peraturan.bpk.go.id/Home/D etails/31506/peraturan-bpk-no-1tahun-2017

Faizah., \& Zuhdi, R. (2013). FaktorFaktor Yang Memengaruhi Kualitas Pemeriksaan (Studi pada Auditor BPK Perwakilan Jawa Timur). Journal of Auditing, Finance, and Forensic Accounting, 1(2), 83-98. doi:

https://doi.org/10.21107/jaffa.v1i2. 4004.g2905

Ghozali, I. (2018). Aplikasi Analisis Multivariate dengan Program IBM SPSS 25 (9th ed.). Semarang: Badan Penerbit Universitas Diponegoro.

Hartanto, F. M. (2009). Paradigma Baru Manajemen Indonesia. PT Mizan Publika.

Ilham, M., Suarthana, W. R, Surono, S. E. (2018). Pengaruh Kompetensi, Integritas, dan Motivasi Terhadap Kualitas Audit (Studi Empiris pada Inspektorat Kota Bogor). Jurnal Online Mahasiswa Bidang Akuntansi, 5(5). Diakses dari https://jom.unpak.ac.id/index.php/a kuntansi/article/view/1060

Jensen, M. C., \& Meckling, W. H. (1976). Theory of The Firm: Managerial Behavior, Agency Costs and Ownership Structure. Journal of Financial Economics, 3(4), 305-360. doi: https://doi.org/10.1016/0304405X(76)90026-X

Layli, M., \& Arifin, J. (2020). Pengaruh Kompetensi, Independensi, dan Kemahiran Profesional Terhadap Kualitas Audit. Jurnal Perilaku dan Strategi Bisnis, 8(2), 152-158. doi: https://doi.org/10.26486/jpsb.v8i2.1 $\underline{310}$

Nirmala, R. P. A., \& Cahyonowati, N. (2013). Pengaruh Independensi, Pengalaman, Due Professional Care, Akuntabilitas, Kompleksitas, dan Time Budget Pressure Terhadap Kualitas Audit (Studi Empiris pada Auditor KAP di Jawa Tengah dan DIY). Diponegoro Journal of Accounting, 2(3), 1-13. Diakses dari https://ejournal3.undip.ac.id/index.p hp/accounting/article/view/3468

Pikirang, J., Sabijono, H., \& Wokas, H. R. N. (2017). Pengaruh Tekanan Waktu, Independensi dan Etika Auditor Terhadap Kualitas Audit di Kantor Inspektorat Kabupaten Kepulauan Sangihe. Going Concern: Jurnal Riset Akuntansi, 12(2), 717-732. doi: https://doi.org/10.32400/gc.12.2.18 $\underline{034.2017}$

Ramadhan, A. (2019, September 25). KPK Tetapkan Anggota BPK Rizal Djalil sebagai Tersangka Kasus SPAM. Kompas.com. Diakses dari https://nasional.kompas.com/read/2 019/09/25/18095321/kpk-tetapkananggota-bpk-rizal-djalil-sebagaitersangka-kasus-spam

Rizal, N., \& Liyundira, F. S. (2016). Pengaruh Tekanan Waktu dan Independensi Terhadap Kualitas Audit (Studi pada Kantor Akuntan Publik di Wilayah Malang). Jurnal Penelitian Ilmu Ekonomi Wiga, 6(1), 45-52. Diakses dari https://media.neliti.com/media/publ ications/164522-ID-pengaruh- 
tekanan-waktu-dan-

independensi.pdf

Sari, E. N., \& Lestari, S. (2018). Pengaruh Kompetensi dan Time Budget Pressure Terhadap Kualitas Audit pada BPK RI Perwakilan Provinsi Sumatera Utara. Jurnal Riset Akuntansi Dan Keuangan, 6(1), 81-92. doi:https://doi.org/10.17509/jrak.v6 $\underline{\mathrm{i} 1.11280}$

Sugiyono. (2010). Metode Penelitian Pendidikan: Pendekatan Kuantitatif, Kualitatif, dan $R \& B$. Bandung: Alfabeta.

Supriyono, R. (2018). Akuntansi Keprilakuan. Gajah Mada University Press.
Susilo, P. A., \& Widyastuti, T. (2015). Integritas, Objektivitas, Profesionalime Auditor dan Kualitas Audit di Kantor Akuntan Publik Jakarta Selatan. Jurnal Riset Akuntansi Dan Perpajakan JRAP, 2(1), 65-77. doi: https://doi.org/10.35814/jrap.v2i01. $\underline{97}$

Syafitri, W. (2014). Pengaruh Keahlian, Independensi, Pengalaman Audit dan Etika Terhadap Kualitas Auditor pada Inspektorat Provinsi Kepulauan Riau. Skripsi. Universitas Maritim Raja Ali Haji Kepulauan Riau. Diakses dari http://jurnal.umrah.ac.id/?p=1945 